\title{
MIMETIC DESIRE AND SCAPEGOAT MECHANISM IN SPORT
}

\author{
Jernej Pisk
}

St. Stanislav's Institution, Ljubljana, Slovenia

Submitted in October, 2011

BACKGROUND: The most fundamental question about sport is what is sport, what is its origin and its essence? Because sport is connected with the human being (there is no sport without human beings) different anthropological visions of human being result in different understandings of sport.

OBJECTIVE: The objective of this paper is to present and explain an anthropological vision of the human being and society as was developed by René Girard. In his view mimetic desire and the scapegoat mechanism have a central role in any culture, religion or other secular institutions. The explanatory power of his theory is presented when it is applied to the world of sport.

METHODS: Our methodology is philosophical, involving conceptual analysis and the application of the outcomes to sport.

RESULTS: In the paper we show that mimetic desire can be recognized as one of the important origins of recreational and competitive sports. When people recognize what other people are able to do or accomplish in sport this invokes the mimetic desire as a result of which motivation for sport and competiveness can arise. But mimetic rivalry leads to an unstable situation. Therefore a second element is needed: Scapegoating in sport is presented as a mean to preserve the good reputation of sport, to keep peace in sport as well as in society as a whole. Finally, the attempt to overcome mimetic desire and scapegoating in sport is presented and the question if this is worth trying at all is opened.

CONCLUSIONS: The theories of mimetic desire and scapegoat mechanism have great explanatory power when they are applied to the field of sport. They could reveal us some hidden motives and forces which drive athletes and sport as a whole. Moreover, they exceed the world of sport and reveal the influence of sport on the whole of society.

Keywords: Sport, philosophy of sport, ethics of sport, competitiveness, mimetic desire, scapegoat mechanism, René Girard.

\section{INTRODUCTION}

René Girard (born 1923) is a French-American cultural critic and one of the most important modern anthropologists, philosophers of social sciences, historians and literary critics. He is especially well known because of his theory of mimetic desire and scapegoat mechanism which, in his opinion, have central role in any culture, religion or in other secular institutions.

Girard's mimetic theory has three structural elements: that our desires are to a large degree imitated or derived through "mimesis"1; that societies have a tendency to channel the violence which arise as a result of mimetic interaction by means of a process of "scapegoating”, which underlines not just religious practices (such as sacrifice) but also secular institutions; and finally, that the revelation which occurs in the Jewish and Christian scriptures is the primary force responsible for showing us the truth about this hidden violence, and for enabling alternative ways of structuring human

\footnotetext{
${ }^{1}$ Mimesis ( $\mu$ í $\mu \eta \sigma \varsigma$ from $\left.\mu \mu \varepsilon \hat{\sigma} \sigma \theta \alpha \imath\right)$ in its simplest context means "imitation" or "representation" in Greek.
}

living. Our paper will focus on the first two elements of Girards' mimetic theory and show how this model can be recognized in everyday sport, while the third element will be used to show the vision of sport liberated of mimetic desire and scapegoating violence.

Girard is not the first and not the only scholar who recognized the importance of desires and mimesis in human life. Also other great thinkers have recognized importance of them for the human being, just to mention Plato, Aristotle, Hobbes, Hegel, Nietzsche and Freud to name a few. Plato recognized mimesis as an important means for art and artists but on the other hand he gave it a negative assessment based on his realism of Forms (Plato, 2004, Republic, p. 373). In Plato's view, art as the imitation of things in the physical world, which are already less real, is less valuable because it is twice removed from Forms. Beside that Plato in X. book of his Republic considers mimesis to be dangerous or problematic, and it is precisely this mystery which Girard thinks he has solved. Aristotle recognized imitation as the essential component in human growth, education, and various artistic activities. 
He argued that human beings are mimetic beings, feeling an urge to create art that reflects and represents reality. In Poetics he said: "Man is distinguished from other life-forms by his capacity for imitation" (Aristotle, 1998, 48b, p. 6-7). All human learning, and especially the acquisition of language, takes place through mimesis/imitation. In Leviathan, Hobbes makes a step further and try to explain violence as a consequence of desire: "This equality of ability produces equality of hope for the attaining of our goals. So if any two men desire a single thing which they can't both enjoy, they become enemies; and each of them on the way to his goal (which is principally his own survival, though sometimes merely his delight) tries to destroy or subdue the other" (Hobbes, 2004, p. 57). Similarly, that desires lead to competitiveness and violence - recognized also by Girard. But Girard's solution of the problem of (mimetic) violence is not the same as is suggested by Hobbes. Hobbes suggests that there must be a common power that can overcome them all and keep them at peace. Hobbes' view is essentially a pessimistic view of human affairs, since it assumes that without a superior force peaceful coexistence between human beings is impossible. On the other hand Girard, as will be presented below, emphasizes the role of scapegoat which (mimetically) unites enemies because it directs their focus to one scapegoat and as result it brings peace to them again.

Beside desires which originate from acquisitive mimesis, Hobbes and Hegel recognized the importance of desire for recognition. It has a central role in the formation of the self ${ }^{2}$. Hobbes wrote: "Every man wants his associates to value him as highly as he values himself; and any sign that he is disregarded or undervalued naturally leads a man to try, as far as he dares, to raise his value in the eyes of others. For those who have disregarded him, he does this by violence; for others, by example" (Hobbes, 2004, p. 57). Similarly, for Hegel the human being is more than just a "thinking subject" (Descartes), so in order to be able to say "I", a subject must have desire. This desire must transcend human animal nature - it has to be a non-natural object of desire. For Hegel, the only possible candidate for such an object is the desire of another. Alexandre Kojève in his "Introduction to the reading of Hegel" writes: "It is human to desire what others desire, because they desire it. Thus, an object perfectly useless from the biological point of view (such as a medal, or the enemy's flag) can be desired because it is the object of other desires. Such

\footnotetext{
${ }^{2}$ A similar claim was made by Joachim Bauer, a modern neurologist and psychiatrist at University Hospital in Freiburg and author of the book "The Principle of Humanity - why do we co-operate by nature?" Based on current medical studies he concludes that physiological motivation systems in human body are activated with the desire and possibility of personal recognition (Bauer, 2008, 29).
}

a Desire can only be a human Desire, and human reality, as distinguished from animal reality, is created only by action that satisfies such Desires - human history is the history of desired Desires" (Kojève, 1969, p. 6). Kojève compares the importance of human desire with the importance of food for animals: "Man "feeds" on Desires as an animal feeds on real things. And the human I, realized by the active satisfaction of its human Desires, is as much a function of its "food" as the body of an animal is of its food" (Kojève, 1969, 6). Therefore, to become a human being in fullness one must risk his life to satisfy his human desire. For Hegel, finally, desire of the human being is to be the value desired by the other: "I want him to "recognize" my value as his value, I want him to "recognize" me as an autonomous value" (Kojève, 1969, p. 7). All human desires are therefore a function of the desire for "recognition". Because of desire for recognition it is worth risking one's own life. To be recognised by the other person, to place oneself as the object of someone else's desire is for Hegel central for the constitution of self-consciousness. So, for him human existence is unthinkable without bloody war for prestige, conflicts in which, paradoxicallly, "man will risk his biological life to satisfy his nonbiological desire" (Kojève, 1969, p. 41). The subject's desire for recognition is so overwhelming that he is prepared to fight for it unitil the end, and sport is no exception here (Pisk, 2012).

Hegel's analysis of the role of desire in human life has many common points with the findings of Rene Girard, however there are important differences between Hegel and Girard. Above all they differ in their understanding of desire. Kirwan sums up differences saying: "Hegel speaks of "desiring the desire of the other" (in other words, I desire that the other should desire $=$ recognize me), while Girard's mimetic theory holds that I "desire according to the other" (my desire is directed according to what the other desires - I yearn for the same object as she does, whatever it may be)" (Kirwan, 2005, p. 33).

Not only human sciences, also modern empirical sciences have discovered the importance of imitation in human development and during the whole life. The discovery of mirror neurons has brought new insights into scientific researches on mimesis (Garrels, 2006). Interesting is that Girard discovered the role of mimesis not through modern empirical researches, but through investigation in literature, cultural anthropology, history and religious texts, all in the time when concept of imitation was quite out of fashion. Because of great explanatory power regarding numerous of cultural forms, including sport, but with still some gaps of empirical evidence Serres (2005) compare Girard's theory of mimetic desire with Darwin's theory of evolution, while declaring Girard as the Darwin of the human sciences. 


\section{GIRARD'S THEORY OF CULTURE}

Girard's mimetic theory ${ }^{3}$ begins with the realization of the importance of mimesis in human desire ${ }^{4}$. Human beings learn from one another what they should desire. In this respect, humans are "mimetic", they copy one another not just in terms of language, gesture and other external attributes, but also in terms of what they desire. Mimetic theory challenges the systems of thought that see an individual as an autonomous subject, who freely and independently choose what he wants and what he does not want. Girard calls this "the Romantic Lie". Despite the ideology of the culture of individualism, we borrow our desires from others. Where mimesis leads to a convergence of desires upon the same object - as with the example of children arguing over toys or as in the case of athletes desiring to win the same gold medal - the result will often be conflict and competition (Girard, 2006, p. 22).

Here Girard distinguishes two kinds of mimetic desires: Desire oriented towards the possession of objects (the child's toy, the gold medal in sport...) is referred to as "acquisitive" mimesis. Where desire is directed beyond objects at some less specific, quasi-transcendent state of well-being or fulfillment, it is known as "metaphysical" desire. Far from being autonomous, our desire for a certain object is provoked by the desire of another person - the model - for this same object. Therefore, desire has a triangular structure, three elements: A desires B because C desires it. Subject's desire for an object is mediated by that of the model ${ }^{5}$. Girard often cites the example of children playing in a room full of toys, where two or more of them want to play with the same toy, even though there are plenty to play with around. "The mimetic quality of childhood desire is universally recognized. Adult desire is virtually identical, except that (most strikingly in our own culture) the adult is generaly ashamed to imitate others for fear of revealing his lack of being. The adult likes to assert his independence and to offer himself as a model to others; he invariably falls back on the formula "Imitate me!" in order to conceal his own lack of originality. Two desires converging on the same object are bound to clash. Thus, mimesis coupled with desire leads automatically to conflict" (Girard, 1977, p. 146). Conflict is especially clear in the desire for a

\footnotetext{
${ }^{3}$ Some connect it with psychology and call it "theory of psychological mimesis": "Psychological mimesis is the tendency of human beings to imitate the gestures, behaviors, and intentions of other persons; it is the very cornerstone upon which the entire work of Girard is constructed" (Garrels, 2004, 2).

${ }^{4}$ It is important to distinguish human desires from need or appetite, in so far as appetites are biologically preconditioned (hunger, thirst), whereas desire is much more a function of culture.

${ }^{5}$ At this point we will not pose the question how, then, the first person starts to desire certain object.
}

material object. If one person takes it and have it, then the other person can not have it. In general the materialistic world view leads to competition for material goods, while the non-material goods (like love) can be devided without inflaming the conflict. This could be recognized in sport competitions since only one can win and receive a gold medal, while in non competitive sport such conflict hardly arise, however mimetic desire still works but on "metaphysical" level.

Girard emphasizes that human nature is imitative: "We must understand that desire itself is essentially mimetic, directed toward an object desired by the model" (Girard, 1977, p. 146). The nature of desire can be best illustrated as a triangle, i.e. as a relation between subject, model and object (Kirwan, 2005, p. 17).

Fig. 1

Triangular structure of mimetic desire

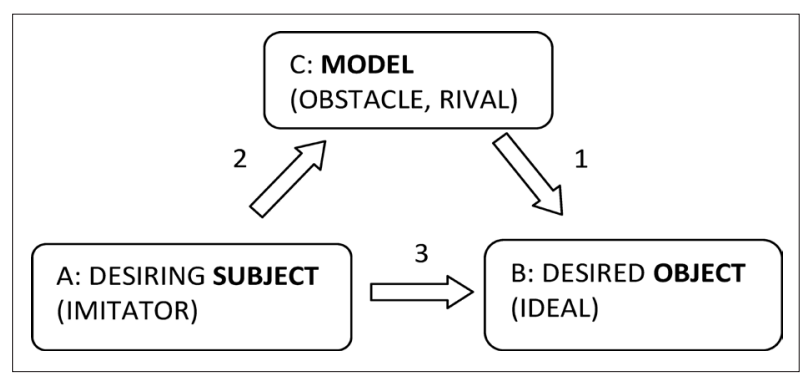

Regarding the distance between the subject and the model Girard distinguishes external and internal mediation. This is important because it can explain why sometimes mimesis leads to conflict and sometimes not. External mediation occurs where the distance between subject and model is greater, and therefore there is no danger of them coming into rivalry. This could be the case when athletes compete in the same sport, but in different categories, therefore they do not feel special rivalry between them. Internal mediation occurs where subject and model occupy the same social space and are capable of entering into competition with one another. This is a more "dangerous" model common between athletes in front of the same task to accomplish; athletes in the same competition.

With this Girard distances himself from theories of human nature which posit an aggressive drive or instinct as the source of human conflicts (as in the case of Thomas Hobbes' theory). They are not natural appetites which drive human beings to conflicts, but desires which are much more conditioned by culture and social interactions. People often do not know what they want - therefore they imitate the desires of others. A number of economic theorists have in fact attempted to utilise mimetic theory in their analyses of market behaviour. Advertisements are relying on mimetic desire in their commercials, while presenting happy people 
(models) using or possesing different goods (desired object), to atract our attention and catch our desire on the desired object of the model. Also athletes serve as a widely used models for commercial purposes. Today, it is impossible to imagine professional sport without the support of sport marketing and different sport trademarks.

If one individual desires something, there will soon be the second one, then the third, then a fourth desiring the same etc. Since from the beginning the desire is aroused by the other (and not by the object) the object is soon forgotten and the mimetic conflict transforms into a general antagonism. At this stage of the crisis the antagonists will no longer imitate each other's desires for an object, but each other's antagonism. They want to share the same object, but since the real object of their desire is "metaphysical", that is, the desire of the desire of the other. They will no longer desire the desired thing, but they will focus on one another as their opponents. This mechanism leads to violence and must be counterbalanced by a mechanism that helps to quell the violence and restore order. At this point the "scapegoat mechanism" is used as a mean for establishing and maintaining social order. According to Girard the crisis is resolved by a realignment of the aggression "all against one". A problem which arises because of mimetic interaction is resolved in the same way; the mechanism can also provide a solution - by one person, then another, and finally the whole group pointing a finger at the alleged cause of the disturbance. The violence against one of the contestants can be imitated by others without necessarily breeding new rivalry - on the contrary, imitating a violent action against a combatant will lead to reconciliation. "A pointing finger will be repeated by others, and quickly the strife of "all against all" becomes a war of (nearly) all against one, or some. The victim will be set upon by the whole group; he or she may be expelled, or put to death. This new mimesis of "all against one" unites rather than divides. It is the reconciliation and sense of unity" (Kirwan, 2005, p. 48). The victim is understood as the embodiment of all evil, and appears to the mob to be responsible for the crisis. Girard gives this victim its everyday name, "scapegoat", while he calls this process, by which the mimetic crisis is resolved, the "scapegoat mechanism" (Girard, 2011). We can find this mechanism of scapegoating also in the world of sport. In sport competitions, however, the resolution of mimetic conflict is mostly conditioned with the end of competition, but not always. The most obvious example of "scapegoats" are those who are presumably caught on doping tests and then suspended from competition.

After presenting the scapegoat mechanism in ancient religious myths Girard turns to the great works in literature from authors such as Proust, Dostoevsky and Shakespeare, and finally to Jewish and Christian scriptures. In his opinion this is the primary force responsible for showing us the truth about this hidden violence, and for enabling alternative ways of structuring human lives. Girard speaks of an opposition of "myth" and "gospel". "The whole thrust of the biblical revelation runs in the opposite direction to myth as he has defined it. God is on the side of the innocent victim, not of the persecutor; the Bible operates as a critique and condemnation of sacrificial scapegoating, not as an example of it" (Kirwan, 2005, p. 63). The question is if this recognition of imitated desires, violence and scapegoating as a components of today's sport reality would be powerful enough to influence the transformation of sport in a new direction. Would athletes, officials and spectators accept such a radical change of perspective?

\section{MIMETIC DESIRE AND SCAPEGOAT MECHA- NISM IN SPORT}

One of the incontestable facts of our time is the presence of competitiveness in all aspects of our life. Without doubt, competitiveness has an important role in the sphere of sport as well. In sport we have to deal with competitiveness on different levels (in physical education, recreational sport and elite sport) and in all possible forms (competitiveness toward other athletes or toward my own self). Therefore, the theory that can at least partly explain the origin of competitiveness can significantly increase our understanding of us as human beings, our endeavor in sport and sport as such.

Above we saw that human beings often learn from one another what they should desire. The connection between mimesis and desire has been exposed many times through human history. Remember, that Hobbes and Hegel both recognized that mimesis lead to competitiveness among human beings. Especially in the cases when both subjects are trying to win the same object which only one can posses at the same time (Girard is calling this "acquisitive" mimesis). The role of desire in human life can therefore at least partly reveal the origin and central role of competitiveness in such human activities as is sport. The object of desire in sport could be different. Probably the most common example of desire in competitive sport is to win, to gain desired recognition garnered by champions, and get medals. This leads to competitiveness because the opposition of the one who is the source of my desire (the model, the other athlete) only strengthens my desire. So imitation of what other desire arises the competitiveness. And when there is an opponent, another competitor, this only confirms that our desire is well grounded and that the value of our desired object is high. This works also in opposite direction: When athletes imitates the desire 
of his opponent, this arises the belief in opponent that his desire is well grounded. The consequences of this is that the intensity of desire is doubled which again unavoidablly leads the rise of competitiveness (Girard, 2006, p. 23).

Desires in sport are not directed only into winning a medal, but also toward other achievements, recognition and different personal skills and abilities. It is not only possible to imitate other athletes and their performances, but also my own. My own self, "I", is changing through time, which leads to the possibility of comparing our abilities from the past with these of today. In this sense we can also talk about imitation of the self from the past. For example, when I run on the same track as I was running some time ago, I'm in position not only to compare my actual time or speed of running with that from the past, but my previous result are in front of me as an ideal (desired metaphysical object), while my old self from the past can be accepted as a model. If we adapt three parts of Girard's mimetic theory to the field of sport we can obtain a triangle of relations as presented in Fig. 2.

Girard distinguished two kinds of mimetic desires: Desire oriented towards the possession of objects is referred to as "acquisitive". Where desire is directed beyond objects at some less specific, quasi-transcendent state of well-being or fulfillment, is known as "metaphysical" desire. In sport it is possible to recognize both types of desire - while acquisitive mimesis is obvious in the case of athletes fighting for medals, metaphysical is more hidden but, nevertheless very frequent and important. Metaphysical desire can be desire for the perfect execution of a movement, for gaining personal well-being, body shape, self-actualisation, health, beauty, spiritual experiences and recognition. Besides those people who are directly involved in physical activities, metaphysical desire has an important role in the wider world of sport. Sport marketing uses this: Younger athletes imitate the older ones, recreational athletes imitate professionals - they are wearing the same uniforms, use the same equipment, and even copy training methods and programs which are used by elite athletes - their models. The direction of gravitation is toward a desired object as was presented by sport "stars". They have special "pulling power" for ordinary individuals. Remember the triangular structure of desire: A desires B because C desires it. Subject's desire for an object is mediated by that of the model. Translated into the sport world: Recreational athlete desires some sport equipment because his model (succesfull profesional athlete) has showed to (seemingly) desire it. Media and commercials are prospering from the fact of human mimetic desires. Nevertheless, this is an important means to gain money for professional sport. Today it is not possible to imagine top level professional sport without systematically planned the production of desires through advertisement. Not only media, it seems that top level sport itself needs support of systematically produced desires to obtain motivation for their progress to "Higher, faster, stronger!" Otherwise the question arises, why so many athletes are so obsessed with the Olympic medal? Why is it so important, so desired? It could be said that it is only a piece of metal like any other medal. But, on the other hand, systematically planned cultivation of desire regarding Olympic medals and its broad symbolic meaning, is the way which assure that most athletes are best prepared for their Olympic competition, which lead to the best possible results (the highest possible level of performance). With the winning of an Olympic medal the athlete not only fulfills his desire, but becomes a model himself. Olympic philosophy carefully cultivates and highly valuates the model Olympic athlete. From ancient Olympians until mondern day Olympic champions are presented as a half gods. The Coubertin's idea of "religio athletae" stimulates the adoration of Olympic winners. Becoming the model also means that athlete somehow liberates himself from the mimetic desire, from imitations of others and assert his independence, his authenticity and fullness of being. To live an authentic life, liberated from public opinion, is, according to existentialism, the main task facing each of us (Nesti, 2004, p. 27).

\section{Fig. 2}

Triangular structure of mimetic desire in sport

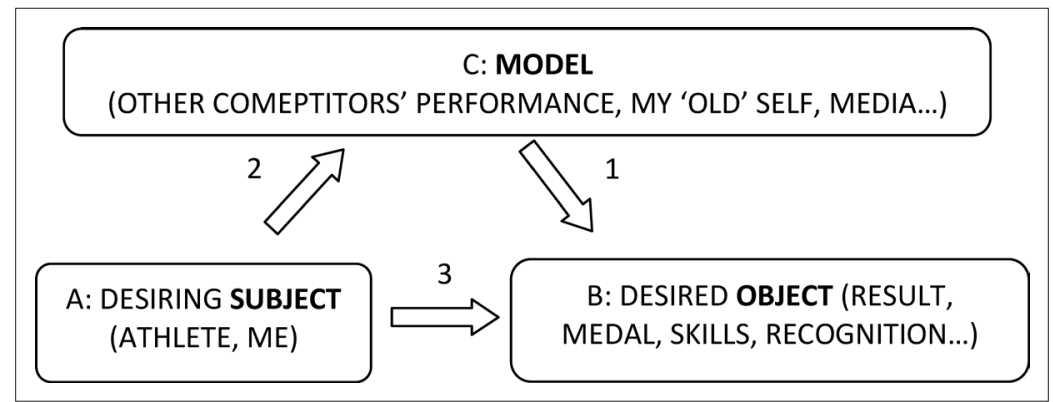


With desire for winning the desire for recognition is closely connected. In some cases this desire can be so powerful that, as Kojève said "man will risk his biological life to satisfy his nonbiological desire" (Kojève, 1969 , p. 41). However, although the subject is prepared to struggle and lose his life, it is also the case that a struggle in which all the combatants are killed would be counterproductive, since recognition is possible only from other human beings.

Therefore one can only want a struggle in which both adversaries remain alive, but in which one yields to the other (this brings to Hegel's famous distinction between the master and the slave, which could be fruitfully applied to the field of sport). And sport competitions seems ideal ground for this: The mimetic desire results in conflict and the struggle after which one is winning, but all others are still alive, and can recognize the winner.

If subject and model do not occupy the same social position, i.e. they are not in the same competition or the same category for the same medal (as is the case when a recreational athlete is imitating a professional, or when a junior athlete is imitating an elite athlete or in the case of male and female athletes), there is no danger for conflict between them, because there is no need for rivalry between them. Girard is calling that external mediation. In it social diferences or other distinctions are able to channel mimetic desire, so the conflictual potential of mimetic desire is never actualised. Where the object can be shared between the desiring parties (as in the case of team sports, where players of one team can share their success), the problem does not occur, but if this is not the case, then rivalry can come about. Where the distance between subject and model is smaller internal mediation occurs. They occupy the same social space and are capable of entering into competition with one another. This is a more "dangerous" model common for competitive sport where athletes are in front of the same task to accomplish, in the same competition, same category. Therefore conflict is unavoidable, because the other is recognized as rival and obstacle. It is a common belief that differences are the origin of conflict, but as Girard insists that it is the erosion of difference which is the dangerous trigger of violence. Experiences from sport confirm this. Sport teaches us that conflict originates from too many similarities - good competition, good "conflict" is possible when many (similarly prepared) athletes are together, trying to accomplish the same task. Athletes in different sports or different categories do not engage in conflict. In this sense sport itself with its organized and non organized promotion of desired objects catalyses conflicts and competitions.

An additional moral problem regarding competitions in sport arises when desires of athletes are no more centered into winning a medal, gaining a wealth or their own performance (desired object) but they center it against another athlete (model). Other athletes are therefore transformed from competitors to opponents or even enemies, while the primary goal of competition - e.g. to win a medal - is eliminated. At first it may ideally seem that any athlete competes only for his own achievement, but since the desire is from beginning aroused by the other (and not by the object) the object (e.g. medal) is soon forgotten and the mimetic conflict transforms into a general antagonism. At this stage of the crisis the antagonists will no longer imitate each other's desires for an object, but each other's antagonism. As the rivalry intensifies, the object (e.g. medal) will become less important, and the rivals become locked into a fascination with each other in a battle for recognition. This has more to do with one's very existence rather any particular object. Therefore, the answer to the question of an athlete during the competition "why compete?" may not be "to win a medal" but instead "to beat the opponent" or "to survive". In such a situation there is hardly any place for "higher" aims of sport as a mean to gain perfection in physical performances etc. All that remains is a fight for one's own "survival" for all cost. In such conditions fair play, which treats other competitors as people and not only as opponents or enemies, could be hard to attain.

Competitiveness and violence which originate from mimetic desires must be somehow regulated and finally eliminated. This is the role of "scapegoat mechanism". Sacrifice of a "scapegoat" leads to channelization of it: people direct their violence in one direction. Such violence is much easier to control and finally eliminate. The result of the process of scapegoating is the return of peace in group or in the whole society.

In sport competitions the resolution of mimetic conflict is mostly conditioned with the end of competition. When time runs out and game is over, the conflict is dissolved. But not always. Probably the most obvious example of scapegoating in sport are athletes who are presumably caught on anti-doping tests and then suspended from further competitions. Because the final aim of anti-doping program is to preserve sport as clean and trustworthy, it doesn't matter if the accused athletes are really using prohibited drugs or not. It even doesn't matter if the anti-doping tests catch all athletes that are abusing drugs. From the point of view of sport (clean and trustworthy sport) or from the intention of those engaged in sport it is even better not to catch all athletes. As Girard has pointed out, the scapegoat mechanism is effective only when the community accuses one (or smaller number) as responsible for this critical situation - this person or a group becomes a scapegoat. Examples of a bicycle race like Tour de France and others support this. Many believe that the 
saying "no dope, no hope" holds. However, to keep the race going on it is not possible and wise to ban too many competitors. To sacrifice some of them as scapegoats would work, and keep the feeling of clean and just competition among the audience. Also an example is of Ben Johnson and Carl Lewis at 1988 Olympics in Seoul support this. As it was recognized later, both athletes tested positive, but only the first one was banned during the Games. As Girard suggests it is important to keep in secret the true nature of what is going on, otherwise the effectiveness of scapegoating decreases. Real situations could reveal that more athletes failed on doping test and that the one accused is really not one among them - he or she could be even completely innocent. But the scapegoat mechanism is working and bringing peace as long as it is believed that the scapegoat is the right one. As in religious myths also in sport it is necessary to perpetuate a silence about violent scapegoating, to keep secret about the true nature of scapegoat. Girard recognized that hiding the truth about the innocence of the scapegoat is one common thing in different religious myths. Only in such conditions the process of scapegoating is effective and brings back peace to a group or society. It seems the head figures of politics and different sport organizations (e.g. IOC, different sport federations etc.) consciously or unconsciously know the mechanism of scapegoating and successfully use it. With scapegoats it is much easier to maintain the good reputation of sport (like sport is good for health; sport develops moral virtues; athletes are moral individuals etc.), and successfully conceal other large problems like chronic health problems of athletes after they finish their career, doping, corruption etc. Girard also emphasized that the best candidate to become a scapegoat is an "outsider" or a stranger, because he or she is less likely to have friends, the state or the powerful NOC behind him or her. No matter who is the scapegoat, it is important to have one. So the "outsiders" can perfectly accomplish this task. There are stories from the past Olympics which tell us that more athletes were found positive on doping tests, however only few of them were accused - more often those from lesser known countries.

The second often used example of scapegoating in sport is not connected with doping but with losing. The nature of sport competitions allows that only one winner and all others lose: "Being second is being the first loser". In this sense sport competitions "produce" losers, so there is open space for scapegoating in sport. Its aim is to eliminate the tension after the failures. Examples of scapegoating inside the group of players, inside the team, sport club, or national sport associations after a failure at the World championship or Olympics etc. are enormous. As rational beings we would like to know the reason for failure, and we can not rest until we find the reason for it. So athletes, players, coaches, sport officials and media search for scapegoats to bring peace back into community. Not only athletes and coaches (it is common practice to sack the coach if the team is not winning, nevertheless he is not fully responsible for the results). Many times the surrogate victim is the referee. For example, after the football match fans of defeated team disappointed with the result often found referee as the guilty. So referees become the scapegoats, which puts a lot of psychical pressure on them and demand a lot of self-confidence. Therefore it's good to have in mind the process of scapegoating after the failure and think about the supposed scapegoat - is he or she really the right one?

Moreover, the consequences of scapegoating in sport are not limited to the sport itself, but can extend to the level of the society as a whole. Sport is not separated from the world, but it is in the world and always has special role in society which exceeds mere competitions - comparing or contesting who is the best. It seems that today sport can be recognized as a one of the important producers of scapegoats in society and therefore, consequently, sport has enormous power to gain and keep peace in it. Not necessarily losers, but those who seem responsible for bad results, unite people and direct their general discontentment to the scapegoat. This was proven many times in the $20^{\text {th }}$ century when different countries used sport as a mean to buy social peace. Nevertheless, those countries often violated human rights and are in very bad economic positions, their athletes usually perform very well and unite people, or if they fail, unite people against a common enemy. But the scapegoating is used to resolve these tensions. It seems that in some degree also modern societies tolerate violence in sport - on the field as well as in the stands for spectators. Sport is "war without shooting”. Sport is place where some of social conflict can be solved, using scapegoat mechanism, whish result in peace in community. This peace can be then transferred to the society. Sport as a competitive activity continually produces scapegoats - the losers - which are symbolically responsible for the crisis of society, and which therefore are used also for protection and assurance of social peace. Obviously it is better for the state to channel violence and aggressiveness in society into sport where people can express their energy and frustrations without any broader unwanted consequences for social order and peace. From this point of view it seems even reasonable for the state to allow some riots among the fans at the stadium. Scapegoating also unites people. If the people are to remain united, they need a common enemy within or without. The scapegoating process will take care of that enemy. It is common experience how big sport events like Olympics or World championship unite nations 
when their team or individuals are competing against another nation, which could be recognized as an enemy. Sport is a source of unification. But not only on the level of international sporting competitions where national teams compete against each other, but also on intra-national level. Nevertheless, sport competitions can result in hooliganism (e.g. in football), sport unites people and calm down tensions in society because it redirects attention to the supposed scapegoat. An "artificial" guilty person (scapegoats) from the limited and more controlled world of sport which connect people in common belief, is much better than to produce riots in wider society. Girard believes that scapegoats found, preserve and unify culture.

\section{CONCLUSION - TOWARD THE NEW SPORT}

The reality of human culture in general as well as sport as a cultural phenomenon in particular reveals us the importance of scapegoating for maintenance of social order and peace. At this point some important questions for understanding and managing of sport arise - what would sport be like without mimetic desires? Is victimization of (innocent) scapegoats in sport morally excusable and worth the price which have to be paid and what would be consequences of revealing the truth of scapegoating for (the future of) sport?

Some predictions could be made regarding consequences for sport if we dismiss the mimetic desire from everyday life. Probably one most obvious changes would be regarding the competitiveness of sport. With recognition and acceptance of human being as directed by mimetic desire, the new light will be put on the (real) value of sport competitions in general and winning in sport in particular. With elimination of mimetic desire from human life, new view on the purpose of sport would arise. To become authentic individuals, athlete will no longer be under the pressure of comparing others and to prove self in front of others (model, object). This could bring new dimension of motivation for sport and new freedom to human physical activities because the reason for being active in sport would no longer come from outside (from others) but just from inside of a person. One such attempt towards the new sport culture was written by Hosta (2010), where he argues for playfulness prior to competitiveness. A key point, he states, for such new culture to flourish is trust: trust in oneself and others to the point where one can be relaxed and playfully released into co-creation of the play environment. Awareness of the whole is the key ethical argument that Hosta provides, if such playful environment is to be created. However, the consequences of sport without external competitions could be negative for sport institutions and media as much as they are grounded on the competitive nature of sport.

Nevertheless, if we accept mimetic desire as a fact about human nature or culture, we still have sacrificial (innocent) scapegoats in sport. As we saw the scapegoating is widely used mean for maintenance of peace in society, but revelation of true nature of scapegoating could result in drastic rise of social unrest. Sport has often been used as a means to master and channel the violence in human societies. But the scapegoat mechanism is a double-edged sword. On one hand, it is good news that we are now aware of how innocent people are frequently victimized in order to maintain social stability inside and outside of the sphere of sport. But, as this awareness spreads, so scapegoating becomes less credible and less effective. If, for example, people will recognize that the athlete who was found positive on doping test was only a "scapegoat" and that more other athletes or sport institutions are not so innocent as they seem, the generally positive reputation of sport for society will be shaken. We can imagine the immense consequences of this. Therefore, for many it seems somehow acceptable to tolerate "violence" in sport and scapegoating if, as the consequence of this, less violence arises in society. However, the permanent questions remain - how much violence is acceptable? Do the ends justify the means? Are there any alternatives? If the scapegoating from society and sport will be dismissed, the whole new paradigm of the living should be established. Has the time for this change already come?

\section{REFERENCES}

Aristotle (350 Before Christ) (1998). Poetics. Orange Street Press.

Bauer, J. (2008). Princip človeškosti. Zakaj smo po naravi nagnjeni $k$ sodelovanju. Ljubljana: Študentska založba.

Garrels, S. R. (2004). Imitation, mirror neurons, \& mimetic desire: Convergent support for the work of Rene Girard. Pasadena: Fuller Theological Seminary.

Garrels, S. R. (2006). Imitation, mirror neurons, and mimetic desire: Convergence between the mimetic theory of René Girard and empirical research on imitation. Contagion: Journal of Violence, Mimesis, and Culture, 12-13, 47-86.

Girard, R. (1977). Violence and the Sacred. Baltimore, MD: John Hopkins University Press.

Girard, R. (2006). Gledam satana, ki kakor blisk pada $z$ neba [I See Satan Fall like Lightning]. Ljubljana: KUD Logos.

Girard, R. (2011). Grešni kozel [The Scapegoat]. Ljubljana: Teološka fakulteta. 
Hobbes, T. (1651). Leviathan (J. Bennett, Trans.). Retrieved 12. 4. 2004 from the World Wide Web: http://gutenberg.org/ebooks/3207

Hosta, M. (2010). Towards a new physical culture; An activist's critique of sport. In M. Hosta (Ed.), Philosophic reflections in sport: A collection of essays (pp. 103-114). Ljubljana: International Institute for Sustainable Development, Policy, and Diplomacy in Sport.

Kirwan, M. (2005). Discovering Girard. London: A Cowley Publications Book.

Kojève, A. (1969). Introduction to the reading of Hegel: Lectures on the phenomenology of spirit. New York: Basic Books.

Nesti, M. (2004). Existential psychology and sport: Theory and application. New York: Routledge.

Pisk, J. (2012). Search for immortality in ancient and modern sport. Physical Culture and Sport. Studies and Research, 54, 5-12.

Plato. (2004). Izbrani spisi [Collected works]. Celje: Mohorjeva družba.

Serres, M. (2005). Discourse de reception. Réponse de M. Michel Serres au discours de M. René Girard. Retrieved 16. 8. 2011 from the World Wide Web: http://www.academie-francaise.fr/immortels/discours_reponses/serres_2005.html

\section{MIMETICKÁ TOUHA A MECHANISMUS OBĚTNÍHO BERÁNKA VE SPORTU}

(Souhrn anglického textu)

VÝCHODISKA: Základní otázky týkající se sportu jsou - co je to sport, jaké jsou jeho kořeny a jeho podstata? Jelikož je sport spojen s člověkem (bez člověka by sport neexistoval), pak z různých antropologických pohledů na člověka vyplývá různé chápání sportu.

CÍL: Cílem tohoto článku je představit a osvětlit antropologický pohled na člověka a společnost tak, jak jej definoval René Girard. V jeho pojetí v jakékoli kultuře, náboženství či sekulárních společnostech hraje ústřední roli mimetická touha a mechanismus obětního beránka. Tuto teorii lze snadno vysvětlit, pokud ji aplikujeme na svět sportu.

METODY: Naše metodika je filosofická a zahrnuje pojmovou analýzu a využití sportovních výsledků.

VÝSLEDKY: V referátu ukazujeme, že mimetická touha je jedním ze základních prvků rekreačních a soutěžních sportů. Když lidé poznají, co jsou jiní lidé ve sportu schopni dělat a čeho mohou dosáhnout, vyvolává to $\mathrm{v}$ nich mimetickou touhu, díky níž vzniká motivace pro sport a soutěživost. Ovšem mimetická rivalita vede $\mathrm{k}$ nestabilní situaci. Je proto potřeba druhý prvek, a to potřeba obětního beránka, který je ve sportu prezentován jako prostředek k zachování dobré pověsti sportu, k udržení klidu ve sportu i společnosti jako takové. Nakonec je prezentován pokus překonat mimetickou touhu i potřebu obětního beránka a otevírá se otázka, zda to vůbec má význam.

ZÁVĚRY: Pokud se teorie mimetické touhy a mechanismus obětního beránka aplikují na oblast sportu, dokáži vysvětlit mnohé otázky, odkrýt určité skryté motivy a síly, jež pohánějí sportovce a sport jako takový. Přesahují dokonce oblast sportu a odkrývají vliv sportu na celou společnost.

Klíčová slova: sport, filosofie sportu, etika sportu, soutěživost, mimetická touha, mechanismus obètního beránka, René Girard.

\section{MA Jernej Pisk}

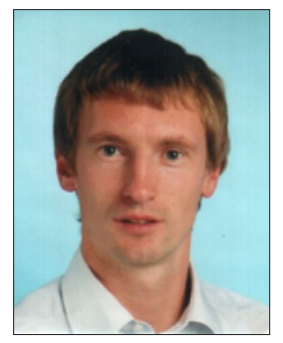

St. Stanislav's Institution

Štula 23

1210 Ljubljana Šentvid

Slovenia

\section{Education and previous work experience}

Degree in physical education, Master of arts in philosophy. Work experience - lecturer on philosophy and physical education.

\section{First-line publications}

Pisk, J. (2012). Search for immortality in ancient and modern sport. Physical Culture and Sport. Studies and Research, 54, 5-12.

Pisk, J. (2011). Sport: The treasure of temperance. Physical Culture and Sport. Studies and Research, 51, 53-61.

Pisk, J. (2006). What is good sport: Plato's view. Acta Universitatis Palackianae Olomucensis. Gymnica, 36(2), 67-72. 